\title{
PATRIARCHAL IDEOLOGY AS SOURCE OF NORMS OF LAW: THE CASE OF EXILED BRIDES
}

\author{
HUKUK NORMLARININ KAYNAĞI OLARAK ATAERKIIL IDEOLOJİ: \\ SÜRGÜN GELİNLER ÖRNEĞI
}

\author{
ПАТРИАРХАЛНАЯ ИДЕОЛОГИЯ КАК РЕСУРС \\ ЗАКОНОДАТЕЛЬНЫХ НОРМОВ: НА ПРИМЕРЕ ИЗГНАННЫХ \\ HEBECT
}

Hicran KARATAŞ*

\begin{abstract}
Law, from archaic times until today, has corresponded to a cultural system regulating the relationship and activities between individuals by determining mutual rights and responsibilities. Yet, every practice that is formed in Folk Law becomes functional in parallel with the social institutions of the society it comes from. Folk Law guarantees the functions that social institutions face in communal living. In order to provide the continuity of institutions like family, economy, education and religion it is equipped with various arrangements. In addition to law order, that is reinforced with authority of government or in spite of them, it is seen that folk laws provide the function of establishing order. Positive law regulations these have been reinforced by state authority consists of written norms. In the face of positive law, there are other law orders that the people resort to solve their legal disputes. These kind of orders are defined with the term of Folk Law under a general framework. Folk Law is a body of compulsory, liable, punitive or forgiving verbal rules these guarantee the rights of individual in the process of socialization by defining them as responsibilities to other members of social group. The literature shows that even small-scale social groups, which share at least one common cultural element, have developed effective folk law orders that can not be ignored. These arrangements are often applied by the people when it comes to legal disputes, and sometimes they are able to function much faster and more effectively than positive ss. In this context, it has academically confirmed and examined that the order function is also met by folk law systems. This reality can be explained in the field of social sciences on the axis of pluralistic law theory and cultural relativity. Thus, the processes of producing, supervising and implementing norms of nonstate law orders can be described. The research will be discussed through local patterns of how is positive law tested by folk, culture, subcultures in the framework of patriarchal ideology and gender. The objectivity and neutrality of law becomes open to interpretation When it comes to application of norms within the framework of patriarchal ideology. Under these conditions, legal norms are represented in the field of trial with different practices in terms of gender. The influence of the patriarchal ideology, which acts as a norm source of law, on a traditional method of punishment shall be discussed as well.
\end{abstract}

Key Words: Folklore, Folk Law, Law, Patriarchal Ideology, Exiled Brides

*Dr., karatashicran@gmail.com

DOI:10.17498/kdeniz.431697 


\section{$\ddot{O Z Z}$}

Hukuk, kadim zamanlardan günümüze kadar uzanan zaman içinde, topluma üye olan bireylerin karşılıklı hak ve sorumluklarını belirleyerek, bireyler arasındaki ilişki ve faaliyetleri düzenleyen kültürel bir sisteme karşılık gelmektedir. Aile, ekonomi, eğitim, din, toplumsal cinsiyet gibi kurumların sürekliliğine katkı sağlamak adına çeşitli düzenlemelerle donatılmıştır. Devletin otoritesiyle güçlendirilmiş pozitif hukuk kuralları yazılı normlardan oluşmaktadır. Pozitif hukuk karşısında halkın hukuki ihtilaflarını çözümlemek için başvurduğu başkaca hukuk düzenleri de bulunmaktadır. Bu düzenler genel bir çatı altında halk hukuku terimiyle tanımlanmaktadır. Halk hukuku, bireyin toplumsallaşma sürecinde haklarını teminat altına alan; bu hakları sosyal grubun diğer üyelerine de sorumluluk olarak tanımlayan emredici, yükümlü kılan, zorlayan, cezalandıran veya bağışlayan sözlü kurallar bütünüdür. Literatür en az bir ortak kültür unsurunu paylaşan görece küçük ölçekli sosyal grupların bile yok sayılamayacak kadar etkin halk hukuku düzenleri geliştirdiğini göstermektedir. Söz konusu düzenler, halkın hukuki anlaşmazlıklar söz konusu olduğunda başvurduğu ve zaman zaman pozitif hukuk düzenlerinden çok daha hızlı, etkili işlev karş̧layabilmektedir. $\mathrm{Bu}$ bağlamda hukukun omurgasını ayakta tutan düzen sağlama işlevinin halk hukuku düzenleri tarafindan da karşılandığı akademik çevrelerce gözlemlenmiş ve doğrulanmıştır. Bu gerçeklik, sosyal bilimler alanında Çoğulcu Hukuk Kuramı ve kültürel görelilik ekseninde açıklanabilmektedir. Böylece devlet dışı hukuk düzenlerinin normlarını üretme, denetleme ve uygulama süreçleri tasvir edilebilmektedir. Araştırmada, pozitif hukukun halkla, kültürle ve alt kültürlerle ataerkil ideoloji ve toplumsal cinsiyet çerçevesinde nasıl sınandığı Sürgün gelinler örneği üzerinden tartışılacaktır. Hukukun nesnelliği, tarafsızlığı hukuk normların uygulama alanında ataerkil ideoloji çerçevesinde yoruma açık hale gelmektedir. Bu şartlar altında, hukuk normları kadınlar ve erkekler açısından farklı uygulamalarla yargılama alanında temsil edilmektedir. Hukukun norm kaynağı olarak ataerkil ideolojinin gelenekselleşmiş bir cezalandırma yöntemi üzerindeki tesiri tartışılacaktır. Gelinler.

Anahtar Kelimeler: Hukuk, Halkbilimi, Halk Hukuku, Ataerkil İdeoloji, Sürgün

\section{АННОТАЦИЯ}

Законы из древних времён по сей день определяют общие права и обязанности лиц, являющихся членами общества и соответствуют той системе культуры, которая регулирует отношения и действия между отдельными членами.

Для того, чтобы поддержать непрерывность социальных в каждой семье имеется различные регульяции. Известно, что правовые нормы составльяются в письменном виде и поддерживаются государством.

Кроме законных прав, существуют и другие правовые схемы, к которым люди прибегают с целью разрешения разных конфликов.

Они назывыются как народное право и защищает права человека в процессе социализации. В нём определяется ответственность перед другими членами социальной группы и состоит из императивных, ответственных, убедительных, наказаемых или прощающих словетсных норм.

По литературе определяется, что даже малые социальные группы разработали эффективные схемы народного права, которые нельзя игнорировать, поскольку они по меньшей мере имеют один общий культурный элемент. 
Такие способы часто применяются людьми, когда речь идет о правовых конфликтах и иногда они могут функционировать гораздо быстрее и эффективнее, чем другие правовые схемы.

В этом контексте наблюдается, что наряду с законными правовыми нормами функционируют нормы народного права.

Такую реальность можно объяснить в контексте социальных наук и плюралистической теории правоведения.

Таким образом, совместно с государственными прововыми нормами и народного права можно расматривать разные процессы в обществе.

В исследовании в гендерном контексте и на примере случаев изгнанных невест, рассмотриваются нормы закона, влияющие на публику, культуру и субкультурах при патриархальной идеологии.

Объективность закона становится понятной во время применении подходов нейтралитета для понятия патриархальной идеологии.

В таких условиях очевидно, что в области юриспруденции правовые нормы народного права в отношении женского и мужского пола представлены по рвзному.

Там же обсуждаеться роль патриархальной идеологии, как источника правовых норм в случае традиционного метода наказания.

Ключевые слова: право, фольклор, народное право, патриархаллная идеология, изгнанные невесты.

\section{Introduction}

Law, as a normative and positive science, analyses the rules established by the state in terms of individual, society and state. Law's being a normative science arises from law doctrine. Law doctrine is that rules of order established by the state are seen as the dominant and unique means of order. In the field of positive/official law, law is an order in which public order in society is protected by the rules established by the legislative organs that are authorised by the state ${ }^{1}$. However, for culture-oriented sciences, the formation of law order is not bound up with the preconditions determined by state authority. Field studies conducted in anthropology, sociology and ethnography of law have revealed that societies without a state authority have idiosyncratic law orders. Hence, the pluralist, relativistic and local structures of law have started to be discussed in the academic platform. Law as a social and cultural phenomenon is an order" which is created, varied, changes and transforms, is observed in different sizes in its different systems in accordance with every society's own social and cultural structure" (Sümer, 1998: 314-315) and it can be produced by other sources aside from the state. Critical approaches to law doctrine started with the studies conducted in the early 19th century. For instance, F. Savigny (1814:28-34) approached law as a historical phenomenon. Law and language are key concepts of folk spirit [volksgeist]. According to the ecole, law starts with traditions. The norms of folk law orders are defined pursuant to traditions. By defining culture, E. B. Tylor ${ }^{2}$ also laid the groundwork for law studies with relativity of culture approach.

E. Durkheim ${ }^{3}$, B. Malinowski ${ }^{4}$, F. Boas ${ }^{5}$, A. Hoebel $^{6}$, L. Pospisil ${ }^{7}$, Ehrlich $^{8}$ laid the groundwork for universality of law and its doctrine to be questioned. Thus, social scientists tended towards studying, analysing, interpreting the legitimate sources, operating mechanisms and applications of folk law orders. 


\section{Folklore, Law and Folk Law}

Folklore is a discipline that address to material and moral cultural products of a country or local community, that compiles, classifies, interprets these products and in the final phase aims to reach a combination of these products with a distinctive method (Örnek, 2000:15). Pursuant to this discipline, folk is "any group of people comprised of two or more people who share at least one common factor" (Dundes, 1965: 2-3). Folk law, which is among the working staff of folklore, aims to compile the legal knowledge of a group that organise all fields of its social life with norms feeding from the same sources, to classify it, to interpret it with reference to the culture of the group and to analyse it within the perspective of cultural relativity and context.

Within the scope of law, the needs of an individual ${ }^{9}$, are "rights"; guaranteeing these rights on satisfaction level is the responsibility of other members of the group. Folk law is "nothing but the archaic and unwritten form of positive law" (Maine, 1879: 12). It is a control mechanism that enables, follows and inspects the socialisation of actions by putting the daily actions of an individual to other people's focus of interest. Folk law is a whole set of oral rules, which "is formed due to the need of cleaning the couch grass in an order in which ordinary and peaceful relationships are considered normal" (Mair, 1975: 36-37), which was developed in an unknown time by the community's ancestors.

Within the frame of folklore, folk law and positive/official law appear as two fields colliding and/or compromising in practise. The fact that folk, despite or in addition to the norms produced by positive/official law, implements another law order successfully to every aspects of social life combines the ways of law and folk law with the same motivation. With this motivation, it can be described how local law orders make their idiosyncratic executive, legislative and judicial processes functional. "For a folklorist, folk law is understanding how folks use law orders, which feed from opposite resources, in unison" (Dundes and Dundes, 1994a: xiv; Bergh, 1994: 18).

Studies conducted in the fields of law and folk law (Chiba, 1998: 239; Er, 1988: 90; Karataş, 2016; Mann, 1993: 283; Moore, 2000: 66-77) have shown that social groups that share factors like ethnical identity, language, religion, kinship, gender, sexual preference, occupation, common grounds (sports, gambling, hobbies etc.) geographical area tend to be subject to their own folk law orders. Thus, undertaking a research in the field of law requires, at least, being familiar with the literature of sub-disciplines in folklore. It is essential to be knowledgeable about oral culture tradition, daily, official behaviours and statements, institutions, religious beliefs and moral values, symbols and rituals to understand the tangible outputs of folk law (Savigny, 1814: 20; Bergh, 1994: 20).

Answering the question of "Why positive law is not enough for organizing the social lives of different social groups in society?" requires understanding knowledge and tendencies of the folk in the field of law. With this question, pluralist legal theory has been developed which steers law and folk law to similar questions with different methods. Within the frame of the theory, societies are comprised of multi-layered cultural, semi independent areas (Chiba, 1998: 240; Moore, 2000: 56-59) and there are folk law orders in these areas. The members of the social group ensure the continuity of their belongingness by being subject to these rules. In this regard, the term social domain means a group that is subject to its own law order. Every social domain has the power to form its own norms of law and enforce them. S. Moore (2000: 56-59) has developed the term semi-independent domain ${ }^{10}$ and described it as "the domain between law-makers and the folk. This domain is the normative environment between statutory law and its own folk law order, the social 
structure itself. It turns to its own law as it is forced into rules by the state. Hence, the capacity of social structure to make law and enforce them becomes legitimate. In this case, a hierarchical order, inclined to compromise or conflict, that can be observed in jurisdiction is formed between law orders.

Studies (Chiba, 1998: 238; Karataş, 2016: 206; Tamahana, 2008: 377; Şahin, 2015: 44-75) suggest that the state is not aware of these law orders and/or ignore them. In these environments, it is seen that it is forbidden by folk norms of law for those who are subject to local law orders to apply to judicial bodies of positive/official law ${ }^{11}$.

In folk law, norms of law equipped with enforcement and other resources are "oral rules of law that are spontaneous without a competent authority and that gained the power to be applied (Işıktaç, 2009: 41). Cultural factors that form the real basis of folk law are traditions. Traditions, by transforming into norms in time, become oral laws.

In this regard, by saying "tradition becomes oral law on the level that it guarantees individual rights, Smith (1927: 269-309) reported that what prevents an individual from committing a crime is the distress caused by the legal sanction of tradition.

Law as a "local knowledge meaning place, time, use, class diversity against pretensions that are coded with rhetorics like a woolsack" is a three-step communication process whose "source" includes "collective justice awareness" [legislation/producing norms], "competent authority to impose sanction" [enforcement/supervising norms] and "sanctions" [jurisdiction/practise]. Source of law and norms are formed by collective justice awareness. In folk law orders, norms obtain their normative values by addressing the cultural factors of the social structure/domain they belong. Cultural factors that form the real basis of folk law are traditions. Traditions, by transforming into norms in time, become oral laws. Taboos, morality, religion and beliefs and ideology get involved in the process as normative source of value.

\section{Patriarchal Ideology as Source of Norms of Law and Exiled Brides}

Social norms are behaviour forms with the capacity of punishing and rewarding ${ }^{12}$ in semi-independent social domains. "Rules that organise individuals' relationships with each other and determine their rights and duties for each other are called norms" (Gündüz, 2005: 20). Social norms are in the position of a guide that shapes the behaviours of an individual. "Norms are to organise human behaviour in order to sustain the unity and solidarity of every community. Norms are behavioural guides for us (Güngör, 2010: 88). They are social control and supervision tools that define behaviours of individuals as right and wrong and determine the limits of these behaviours. Individuals are forced to act accordingly to the social common values and actions with the normative value of norms on social life coded into the law order. Then they are equipped with sanctions. In the last phase, the power that will inspect the norm and impose the sanction is determined. Each law order in which these factors meet the establishing order function is equal of folk law orders.

During the phase in which repetitive behaviours are surrounded with sanctions, the members of the social group show a common reaction. This reaction is the manifestation of culturally formed collective awareness in the field of law. "Behaviours surrounded by sanctions are called norm or tradition [way] (Hoebel, 1954: 14). At the end of a process the course of which is "trial, habit, tradition and competence" (Sumner, 1906: 3) the behaviour turns into norm and it is equipped with sanctions such as gossiping and laughing as light sanctions, and death and exile as severe. 
Norms of law corresponding with the patriarchal ideology appears as a universal phenomenon. "There is no law order in which there aren't any laws that form a basis for discrimination against women (Tucker, 2008: 3). Patriarchal ideology is a construct on which every institution of social structure is formed on the social life and nature of women. "In social organisation, in daily life and in the process of actualising the public decision making processes, it is an order in which men are dominant." (Encyclopaedia of Anthropology, 1979: 296). In Neolithic culture phase, parallel to domestication activity, husbandry replaced hunting; agriculture replaced gathering. The changes that happened in living patterns caused an increase in the need of possession in social domain. The fact that patriarchal family ensures that possession are handed down from father to son by inheritance and the fact that norms of law are formed with regard to patriarchal ideology differentiate the norms that women and men subject to. In this regard, all social institutions from law to education support the norms related to social roles designated for men and women. They are learned and transferred in the process of socialising and thus they are internalised by becoming socialised. Behaviours and preferences which a social structure in a specific cultural environment produce to differentiate its female and male members in regard to their manners, attitudes, rights and liability are social roles attributed to gender.

Relativistic gender roles are effective in the formation of values that determine what is right and what is wrong for female and male gender. As values are measures taken as references for the thoughts, attitudes and behaviours of individuals, norms are produced to reinforce the gender roles in society. "Most norms of law produced in the frame of patriarchal ideology focus on proving how natural and necessary social gender roles are"(Weedon, 2001: 3). Patriarchal ideology's turning into a source of norms happens with "learning gender roles, joining the process of socialisation and internalising"(Connell, 1987: 49). Internalisation of patriarchal ideology is that the sanctions of norms of law related to social gender are presented as natural and legitimate. J. Butler (2008: 10) defines this as naturalising the process. Oral and written cultural products, industrial sources, traditions and rituals of institutions like family, religion and education turn into important means of discourse in the process of naturalising patriarchal ideology. In the course of internalising/naturalising law refers to certain concepts that are clear, covert or hiding behind special words. Purity, virtue, honour are also concepts developed to define behaviours pertaining to the age and status of genders as positive or negative.

These concepts are developed to define those who are subject to the culture itself with reference to their marital status. The status of an individual who doesn't take place in these categories turns into a public matter. In the case that culture cannot be specified in the standard category schema, ambiguousness and anomaly occur. Therefore, culture develops measures and methods to comb out what is ambiguous and abnormal and to normalise them (Douglas, 2000: 40). Virginity, which is accepted as an indicator of sexual purity of unmarried women, is a cultural phenomenon which promises paternity knowledge and promises that the father of the children born will be the same as the first child. "Virginity gives paternity knowledge. Although it is known by birth whose mother is who, it is difficult to prove paternity. Maternity is not questioned but paternity is" (Blank, 2012: 76). This reality is expressed in Turkish culture with an idiom; "only the mother knows whose the child is" (Ergin, 2009: 75; Gökyay, 2009: 21).

When some "out of the norm" behaviours faced with resistance via characteristic sanctions, their sanctions become tradition. Cultural sources, from which the practise named in the social structure as "Bakacak'tan aşırmak/Being banished-deported" feeds in the 
legislation/norm producing process of local folk law order, have been interpreted and have become traditions with regard to patriarchal ideology. The structure's forming around the patriarchal ideology also supports the structural and functional transformations of norms. Premarital sexual activities which require the execution of "Bakacaktan aşırma" punishment is defined as an anti-social behaviour. Norms related to these behaviours are organised by oral cultural traditions of the field and transitional period traditions. Taboos, moral rules are coded as normative values into traditions related to patriarchal ideology and in this phase they are equipped with sanctions.

Our field researches conducted between the years of 2012 and 2016. Interviewed exiled brides who were sent from a total of sixteen villages of one of the two districts, located within the borders of a province ${ }^{13}$ located in Western Black Sea Region in Turkey, to a specific village of the other district experienced the punishment of exile in a local law order which is organized by producing, inspecting and enforcing its own norms. Exiled brides are young women who were put on trial for their premarital out of the norm sexual behaviours and sentenced to exile. The law order, which the exiled brides are subject to, which dates back to 1850 s in oral history, is defined within the frame of field law and terms of legal entity in the context of hypothesis model. These fields take place in geographical regions physically away from the law enforcement of the state and they can be ignored not to go against and not to be threat for the dominant law order ${ }^{14}$. Exile is the temporary or permanent banishment of the criminal herself or along with her family from the social structure due to her anti-social behaviour. The criminal is settled away from the crime scene; she gets deprived of her rights and privileges by removing her from physical, social and cultural environment. It is a practise applied throughout Turkish history of law as a punishment and Turkification policy. In the early periods of Turkish history of law, expressions such as "büke atmak, yabana atmak, catkaya atmak, beyabana atmak"(Çobanoğlu, 2004: 104-105) seem to have been used in the meaning of banishment or exile. In the case that anti-social behaviour poses a risk for the continuity of the social structure/constitution, in order for the criminal to give up hope of turning back to the crime scene, she is settled in the exile-place with some precautions ${ }^{15}$. In the example of exiled brides, these precautions are taken in the form of marrying her off with the other during the execution of sentence by the board of alderman that holds the executive and judiciary power. The agents experimenting this sanction are called exiled brides or "Bakacak'tan aşanlar/being deported" and the explanation for this in the field of folklore is related to exile precautions.

The source of norms that tunes the sexual behaviours of individuals with socialised actions in this field are listed as taboos, moral rules, religion and beliefs. They are coded as normative values into norms by interpreting them within the frame of patriarchal ideology in these sources. The fact that violations of the norms related to sexual life are faced with resistance shows that the said behaviour is not approved culturally. The social function of the punishment of this behaviour is to comb out the said behaviour from social life and to include the individual, who behaved out of norm, in the process of re-socialising in nonrestricted relationships. The punished individual, who is to be combed out, is married off with the other to include her in the socialising process.

The punishment of "bakacaktan aşırmak/being banished-deported" which the exiled brides experience as an agent is closely related to the exercise of "the right to turn from maiden to woman" without giving that right to the man, which is his according to oral or written marriage contract. In the process, women offenders were punished by exile without 
considering the conditions for the out of norm behaviour. "The right to turn from maiden to woman is given to a particular man according to the agreements with the girl's father. This rule and the reaction that the society shows to the girl who behave against this rule and to her parents are the result of patriarchal laws (Boratav, 2013: 39).

In Turkish tacit law, it $\mathrm{s}$ known that out of norm sexual behaviours between single young people aim at restoring the honour and retrieve the lost honour and these out of norm sexual behaviours between single young people are faced with resistance from a compromising approach in trial period. In this regard, men who had premarital sexual intercourse with young women are known to have been punished to pay compensation and/or marrying the women they victimized. In literature ${ }^{16}$, getting married of is reported to have been executed as a punishment. The second phase of Turkish history of law is the compromising and conflicting pluralist law period between Turkish tacit law order and Islamic law. Customs and their sanctions in the field of conflict are sustained in semiindependent social domains while current local folk law order must have turned into the status of closed spaces. In the field of compromise, norms in which customs are not polarised with Islamic law doctrine are defined as a resource of law under the name of manner. Turkish tacit law norms are especially known to be a resource of law in the sentencing of social events that aren't organised by Islamic law norms. In this regard, the fact that all out of norm sexual activities between man and woman are defined as adultery required new regulations for the cases involving single women and men. In the end it was decided that "they would be caned a hundred times and exiled for a year"(Demir, 2011: 99: Özkorkut, 2009: 106, 110; Üçok, Mumcu and Bozkurt, 2011: 96)

In the example of exiled brides, it is seen that purity is associated to married women and chastity is associated to unmarried. The uncertainty in the status of those who don't get married according to the traditions and rituals of marriage transitional period requires the normalisation of the individual and removing the uncertainty of them. Hence, women, who can't acquire their new status within the traditions and rituals of marriage transitional period of the social structure, acquire the standard status of the culture through the traditions and rituals of marriage transitional period of the other.

Norms of sexual morality form the basis for the methods to retrieve the lost honour depending on the honour and chastity which is used to control the sexuality of the unmarried woman who lives in the family home. The situations in which honour is soiled, stained and clouded are temporary. Of the large variety of methods ${ }^{17}$ (Ergil, 1980: 202) developed to retrieve the lost honour, "Bakacaktan aşırmak" is a traditional and local law order punishment which is imposed in particular geographical borders. In the closed law order developed in these borders, the punishment of exile and the method of marrying off with the other as a precaution must have been developed to restore one's honour. Thus, while the women in question are punished by removing permanently from the social structure, they take their places in standard culture categories by getting married off in the new environment they are exiled to. This traditional punishment developed against the out of norm sexual behaviours of exiled brides is one of the numerous methods developed by patriarchal societies to restore the honour which is depended on purity.

\section{Conclusion}

Law, in the process from archaic societies until today, is a body of rules that organize public order by putting the fundamental rights and freedoms of an individual into the area of responsibility and interest of the members of the social group he lives in. As societies are 
comprised of multilayered fields, it has the capacity of forming an idiosyncratic law order in these fields. Law, with its capacity to legislate, enforce and implement, gets institutionalised when it meets the function of establishing order. It is known that there will be a hierarchy between law orders in a society and those norms in this hierarchy may vary within the frame of relationships on the conflict or compromise plane among the law orders. Along with or despite the dominant/official law order of the state, there are law orders that meet the function of establishing order of the law as a social control mechanism. In this order, norms are sustained verbally in the mind of the society. In folk law orders, in which executive and judicial powers against norm violations are attributed to notable people in the group, individuals are referred to socialised actions. In these order, while norms are varied in the form of convention, tradition, custom habit and practice each of them needs to take cultural factors as references in relation to validity. Resources that norms of law refer to in terms of normative value are varied as taboos, moral, religion and beliefs and ideology. Anti-social behaviours of an individual are inhibited by equipping the normative value of the norm with a sanction as severe as the reference sources. Among these sanctions, exile appears as a local and traditional punishment method which is the subject of this study. This method, developed to permanently remove the offender from the social structure, is executed when the norms are violated which are developed within the frame of patriarchal ideology to organise the sexual life of an individual before marriage. As the conditions that soil the honour are temporary, to restore one's honour depending on purity and to redefine women, the subject of chastity, within the standard cultural categories, they are married off as a precaution during the execution of exile punishment. Exile as a traditional punishment, developed against the out of norms sexual behaviour of the exiled brides, is one of the methods developed to restore and defend one's honour in law orders whose norms take their normative value from patriarchal ideology.

\section{Notes}

1. Positive law is that the dominant legal sistem in effect is recognized as the valid legal system. (Bilge, 2004: 35; Güriz, 1996: 9;).

2. Culture is a sum of knowledge, beliefs, art, moral, law, customs and traditions and all skills and habits that humans acquire as a member of society (Tylor, 1891: 54).

3. E. Durkheim $(1982$ : 134,140) established that the guaranteeing factor for the functioning of institutions is law.

4. The resources of the legislative power in the folk law of Trobriand Island has been recorded. Thus, it has been understood that their local law order has its own functioning mechanism and legislation procedures.

5. With a historical and partial approach, he desribed culture as a product of singular processes under the control of independent law rather than a reflection of mechanical cooperation of natural circumstances (1938: 159).

6. He compiled the law developed by lawyers, prosecutors and judges who are specialized in the field of positive/official law with regard to their own professions. The fact that there is a folk law order developed among the professionals dealing with the positive law itself shows that there are a wide variety of law orders available.

7. He recorded that law is a social and cultural phenomenon (1971: 43-48) which is formed as a reaction to culture's need of order.

8 . He recorded the processes of folk law orders that organise actively in modern states of law and named them as living law. (1962: 143). 
9. The most basic needs of an individual are physical needs. When needs such as hunger, thirst, sleep and sexuality aren't met, one doesn't make demands for the needs on the upper level. The second phase is the need of one's security. In social groups in which security is provided, an individual is not protected from wild animals, extremely hot climate, unemployment, but also manages to live confidently without the possible attacks of crimeprone individuals and thus meets the need of said security. The third phase is the need of belonging. In this phase, the individual is completely in the process of socialising. An individual who starts a family and makes friends meets the need of belonging fully in this phase. On the upper level, the need of an individual is to be respected in the society. He demands the respect of the members of the group he belongs to by gaining power, competence, success, talent, fame and dignity. On this level an individual can actualise oneself in fields that require specialisation and creativity in being an ideal individual (Maslow, 1943: 372-383).

10. Z. Gökalp (2013: 26) named them as semisocieties. He recorded that societies that live under the sovereignty of a single state establish order dependantly on their own social institutions.

11. See (Kymlicka, 2010: 77) about the exile of those who resort to the jurisdiction for matters of law among Native Americans. See (Şahin 2015: 88-89) for examples in which those who resort to jurisdiction for matters of law in Alawite law are sentenced from two years to permanent devotion.

12. That rewarding is practised in a more passive field is related to the fact that enforcement mechanisms function with an active sensibility in jurisdiction. In the field of law, an individual is rewarded by being defined as an ideal individual and a model in the social structure.

13. When providing information on sexual, religious, ethnical and legal subjects from the source persons, the ethical responsibility of the researcher is to make sure the safety of the persons. It is recommended that the real names of the source persons and research field are covered in this kind of research. See: (Guenther, 2009: 414; Hicks, 1977: 216; Murchison, 2010: 204).

14. These folk law orders are resilient against disintegration in dominant law order. The state tends to compromise in order to take the load off in these fields. See: (Bergh, 1994: 6-30; Dundes, 1994b: 1-4; Şahin, 2015: 90-93; Tezcan, 1981: 34-35; 2003: 16).

15. See (Arık, 1995: 33; Barman and İpçioğlu, 2009: 248; Er 1988: 60-62; Koran, 1943: 11-12; Kocourek and Wigmore,1908: 282, 287; Radcliffe-Brown, 1965: 218; Tiba, 2010: 25) for precautions of exile such as selling the offenders movable and immovable properties, informing the crime scene and the environment about the actions of the offender, forming a moral registry etc.

16. It has been recorded that marrying off with the victim is practiced as a punishment. See: (Arık,1995: 25; Arsal, 2014: 158; Başar, 2013: 69,72; Şeşen, 1995: 116; Ziya Gökalp, 2015: 88).

17. In societies in which honour is associated with purity and purity is associated with chastity, men are known to have developed various methods to restore their honour due to socio-cultural circumstances and conditions. These methods are varied such as marrying off the victim to her rapist, temporary or permanent removal from the crime scene, having her killed by a family member, hiring a hitman, making it look like an accident, forcing suicide. See: (Ergil, 1980: 202; Gezik, 2003: 113, 126; Tezcan, 2003: 19). 


\section{REFERENCES}

ARIK, Feda Şamil. "Eski Türk Ceza Hukukuna Dair Notlar”. Ankara Üniversitesi Dil ve Tarih-Coğrafya Fakültesi Tarih Araştırmaları Dergisi 28 (1995): 1-50.

ARSAL, Sadri Maksudi. Türk Tarihi ve Hukuk. Ankara: T.T.K. Yayınları, 2014.

BARMAN, Mehmet ve İPÇIOĞLU, Mehmet. "1792-95 Yılları Arasında Osmanlı Konya'sında Sosyal Yaşamdan Kesitler”. Selçuk Üniversitesi Sosyal Bilimler Enstitüsü Dergisi 22 (2009), 239-253.

BAŞAR, M. Serkan. Íslamiyet Öncesi Eski Türk Hukuku. Yayımlanmamış yüksek lisans tezi. Kayseri: Erciyes Üniversitesi, 2013.

BERGH, G. C. F. F. van den. "The Concept of Folk Law in Historical Context". Folk Law: Essays in the Theory and Practice of Lex Non Scripta, New York\&London: Garland Publishing, 5-31, 1994.

BILGE, Necip. Hukukun Bașlangıcı Hukukun Temel Kavram ve Kurumları. Ankara: Turan Kitabevi, 2004.

BLANK, Hanne. Bekâretin El Değmemiş Tarihi. İstanbul: İletişim Yayınları, 2012. 1938.

BOAS, Franz. The Mind of Primitive Man. New York: The Macmillan Company, 2013.

BORATAV, Pertev Naili. 100 Soruda Türk Folkloru. Ankara: Bilge Su Yayınları,

BUTLER, Judith. Cinsiyet Belası: Feminizm ve Kimliğin Altüst Edilmesi. İstanbul: Metis Yayınları, 2008.

CHIBA, Masaji. "Other Phases Legal Pluralism in the Contemporary World'. Ratio Juris, 11/3 (1998), 228-245.

CONNELL, Robert. Gender and Power. Stanford: Stanford University Press, 1987 2004.

ÇOBANOĞLU, Özkul. Türk Dünyası Ortak Atasözleri Sözlüğü. Ankara: AKM Yay.,

DEMIR, Abdullah.Türk Hukuk Tarihi, İstanbul: Yitik Hazine Yayınları, 2011.

DOUGLAS, Marry. Purity and Danger: An Analysis of Concepts of Pollution and Taboo. New York: Routledge, 2000.

DUNDES, Alan. "What is Folklore?". The Study of Folklore, New Jersey: PrenticeHall, 1-3, 1965.

. ve DUNDES,Alison Renteln (1994a). "Introduction". Folk Law: Essays in the

Theory and Practice of Lex Non Scripta, New York\&London: Garland Publishing, XIIIXVI, 1994a.

. "What is Folk Law?". Folk Law: Essays in the Theory and Practice of Lex Non Scripta, New York\&London: Garland Publishing, 1-4, 1994 b. 1982.

DURKHEIM, Emile. The Rules of Sociological Method. New York: The Free Press,

EHRLICH, Eugen. Fundamental Principles of the Sociology of Law. London: Transaction Publishers, 1962.

Encyclopedia of Anthropology. New York: Harper\&Row Publishers, 1979.

ER, Tülay. Simav İlçesi ve Çevresi Yaren Teşkilatı. Ankara: Kültür Bakanlığ Yayınları, 1988

ERGIL, Doğu. Türkiye'de Terör ve Şiddet. Ankara: Turhan Kitabevi, 1980.

ERGIN, Muharrem. Dede Korkut Kitabı. Ankara: TDK Yayınları, 2009.

GEERTZ, Clifford. Yerel Bilgi. Ankara: Dost Kitabevi, 2007 
GEZIK, Erdal. Şeref, Kimlik ve Cinsiyet. Ankara: Kalan Yayınları, 2003.

GÖKYAY, Orhan Şaik. Dedem Korkudun Kitabı. İstanbul: Kabalcı Yayınevi, 2009

GRIFFITHS, John. "What is Legal Pluralism?". Journal of Legal Pluralism and Unofficial Law 24 (1986) 1-38.

GUENTHER, Katja. "The Politics of Names: Rethinking the Methodological and Ethical Significance of Naming People, Organization and Places”. Qualitative Research 9/4 (2009): 411-421.

GÜNDÜZ, Mustafa. Ahlak Sosyolojisi. Ankara: Anı Yayınları, 2005.

GÜNGÖR, Erol. Kültür Değişmesi ve Milliyetçilik. İstanbul: Ötüken Neşriyat, 2010. GÜRIZ, Adnan. Hukuk Başlangıcı. Ankara: Siyasal Kitabevi, 1996.

HICKS, George. "Informant Anonymity and Scientific Accuracy: The Problem of Pseudonyms". Human Organization, 36/2 (1977): 214-220.

HOEBEL, Edward Adamson. The Law of Primitive Man: A Study in Comparative Legal Dynamics. Massachusetts: Harvard University Press, 1954.

IŞIKTAÇ, Yasemin. Hukukun Kaynağı Olarak Örf ve Adet Hukuku. İstanbul: Filiz Kitabevi 2009.

KARATAŞ, Hicran. Halk Hukuku Uygulamalarl ve Sürgün Gelinler. Yayımlanmamış doktora tezi. Ankara: Hacettepe Üniversitesi, 2016.

KOCOUREK, Albert and John Henry Wigmore. Sources of Ancient and Primitive

Law. Boston: Little, Brown, and Company, 1915.

KORAN, Akif. "Yaren". Ülkü 5/54 (1943): 11-12.

KYMLICKA, Will. Çokkültürlü Yurttaşlık. İstanbul: Ayrıntı Yayınları, 1998.

MAINE, Sir Henry Sumner. Ancient Law. New York: Henry Holt\&Co, 1879.

MAIR, Lucy. Primitive Government. Gloucester Mass: Peter Smith Pub. 1975.

MALINOWSKI, Bronislaw. Crime and Custom In Savage Society. London: London: Kegan Paul, Trench, Trubner \& Co., 1975.

MANN, R. S. "Tribal Customs and Laws of Western India an Interpretation". Tribal Ethnography Customary Law and Change, New Delhi: Concept Publishing Company, 281285, 1993.

MASLOW, H. Abraham. "A Theory of Human Motivation", Psychological Review 50/4 (1943): 370-396.

MOORE, Sally Falk. Law as Process: An Anthropological Approach. Oxford: James Currey Publishers, 2000.

MURCHISON, Julian. Etnography Essentials: Designing, Conducting, and Presenting Your Research. San Francisco: Jossey-Bass, 2010.

ÖRNEK, S. Veyis . Türk Halkbilimi. Ankara: Kültür Bakanlığı Yayınları, 2000.

ÖZKORKUT, Ü. Nevin. Türk Hukuk Tarihinde Zina Suçu. Ankara: Siyasal Kitabevi, 2009.

POSPISIL, Leopold. Anthropology of Law: A Comparative Theory. New York: Harper\&Raw Publishers, 1971.

RADCLIFFE-Brown, REGINALD. A. Structure and Function in Primitive Society Essays and Addresses. New York: The Free Press, 1965.

SAVIGNY, Friedrich Carl Von. Vom Beruf unserer Zeit für Gesetzgeburg und Rechtswiss enschaft. Heidelberg: Mohr u Zimmer, 1814.

SMITH, Munroe. A General View of European Legal History. New York: Colombia University Press, 1927. 
SUMNER, William Graham. Folkways: A Study of the Sociological Importance of Usages, Manners, Customs, Mores and Morals. Boston: Ginn and Company, 1906.

SÜMER, Neslihan. "Bir Kültür Ürünü Olarak Hukuk". Ankara Üniversitesi Dil ve Tarih Coğrafya Fakültesi Dergisi 38/1-2 (1998): 313-321.

ŞAHIN, Çağatay. Hukuki Çoğulculuk Bağlamında Alevi Hukuku. Yayımlanmamış yüksek lisans tezi. Ankara: Ankara Üniversitesi, 2015.

ŞEŞEN, Ramazan. İbn Fazlan Seyahatnâmesi. İstanbul: Bedir Yayınları, 1995.

TAMANAHA, Brian. Understanding Legal Pluralism Past to Present, Local to Global. Sydney Law Review 30 (2008): 375-411.

TEZCAN, Mahmut. Kan Dâvâları: Sosyal Antropolojik Yaklaşım. Ankara: Ankara Üniversitesi Eğitim Fakültesi Yayınları, 1981.

Türkiye'de Töre (Namus) Cinayetleri. Ankara: Natürel Yayınları, 2003.

TIBA, Th. Robert. Customary Laws and Proctices of The Maram Nagas. New Delhi: Mittal Publications, 2010.

TUCKER, E. Judith. Women, Family and Gender in Islamic Law. Cambridge: Cambridge University Press, 2008.

TYLOR, Edward Burnett. Primitive Culture Researches into the Development of Mythology, Philosophy, Religion, Language, Art, and Custom. Vol. II, London: John Murray, 1891.

ÜÇOK, Coşkun - MUMCU Ahmet ve BOZKURT Gülnihâl. Türk Hukuk Tarihi. Ankara: Turhan Kitabevi, 2011.

WEEDON, Chris. Feminist Practice and Poststructuralist Theory. Oxford: Blackwell Press, 2001.

GÖKALP, Ziya. Türk Ahlakl. İstanbul: Bilgeoğuz Yayınları, 2013.

—. Türk Medeniyet Tarihi. İstanbul: Ötüken Neşriyat, 2015. 